\title{
Differential Effects of Haloperidol and Clozapine on Neurotensin Gene Transcription in Rat Neostriatum
}

\author{
Kalpana M. Merchant, ${ }^{1}$ Paul R. Dobner, ${ }^{4}$ and Daniel M. Dorsa ${ }^{1.2 .3}$ \\ 'Department of Pharmacology and 'Departments of Medicine and Psychiatry \& Behavioral Sciences, University of \\ Washington, Seattle, Washington 98195, ${ }^{3}$ Geriatric Research, Education and Clinical Center, Seattle VA Medical Center, \\ Seattle, Washington 98108, and ${ }^{4}$ Department of Molecular Genetics and Microbiology, University of Massachusetts, \\ Worcester, Massachusetts 01655
}

\begin{abstract}
A single dose of typical neuroleptic, haloperidol, has been demonstrated to increase the expression of neurotensin/ neuromedin N (NT/N) mRNA in the dorsolateral striatum within $1 \mathrm{hr}$ of its administration (Merchant et al., 1991). The present study further investigated neuroleptic-induced regulation of NT/N gene transcription. Levels of NT/N mRNA were examined at various times following a single dose of haloperidol ( $1 \mathrm{mg} / \mathbf{k g}, \mathrm{i} . \mathrm{p}$.) or the atypical antipsychotic clozapine $(20,30$, or $40 \mathrm{mg} / \mathrm{kg}$, i.p.) by in situ hybridization histochemistry and quantitative solution hybridization. In the dorsolateral striatum, the two drugs had strikingly different effects; haloperidol rapidly (within $\mathbf{3 0} \mathrm{min}$ ) increased the expression of mature NT/N mRNA while virtually no increase was observed in response to nontoxic doses of clozapine at any of the time points examined. Following haloperidol, maximal induction occurred at $7 \mathrm{hr}$, at which time NT/N mRNA levels were an order of magnitude higher than basal levels. By $20 \mathrm{hr}$ after haloperidol, there was a significant decline in striatal NT/N mRNA levels. In situ hybridization analysis using an intron-derived probe revealed that haloperidol-induced increases in mature NT/N mRNA levels in the striatum were preceded by a transient increase in intron-containing NT/N gene transcripts. These data strongly indicate that acute haloperidol treatment results in transient transcriptional activation of NT/N gene, although a concomitant effect on the stability of NT/N primary transcripts cannot be ruled out. In contrast to their differential effects in the dorsolateral striatum, a single dose of both haloperidol and clozapine induced a small but significant increase in NT/N mRNA expression in the shell sector of the nucleus accumbens. These results raise the possibility that NT neurons in the nucleus accumbens may, at least in part, mediate the antipsychotic effects of classical neuroleptics, whereas NT cells in the dorsolat-
\end{abstract}

\footnotetext{
Received May 6, 1991; revised Aug. 28, 1991; accepted Sept. 27, 1991.

We are grateful to Dr. Ariel Deutch for his guidance in anatomical definition of nucleus accumbens core and shell. This research was supported by grants from Washington Institute for Mental Illness Research and Training (K.M.M. and D.M.D.). by Scottish Rite Schizophrenia Research Program (K.M.M. and D.M.D.), by Research Service Department of Veterans Affairs (D.M.D.), and by NIH Grants NS 20311 (D.M.D.) and HL 33307 (P.R.D.). We thank Anne Kalliomaki, Kimberley Donnell, and Cheryl Refsdal for their excellent technical assistance. We are also grateful for the generous gift of clozapine by Sandoz Pharmaceuticals.

Correspondence should be addressed to Kalpana M. Merchant, Ph.D., 182-B, GRECC, Seattle VA Medical Center, 1660 South Columbian Way, Seattle, WA 98108.

Copyright (C) 1992 Society for Neuroscience $0270-6474 / 92 / 120652-12 \$ 05.00 / 0$
}

eral region of the striatum may be involved in mediating other effects of typical neuroleptics such as extrapyramidal motor symptoms.

Neurotensin (NT) is a tridecapeptide originally isolated from bovine hypothalamus (Carraway and Leeman, 1973) and is heterogeneously distributed in the CNS, where it is likely to function as a classical neurotransmitter or neuromodulator (Uhl and Snyder, 1976; Kitabgi et al., 1977; Iversen et al., 1978; Young and Kuhar, 1981; Uhl, 1982). A variety of recent studies indicate that central NT pathways may play an important role in the etiology and/or pharmacotherapy of schizophrenia and other affective mental disorders. For example, anatomical and biochemical evidence indicates that NT modulates dopaminergic pathways (for reviews, see Quirion, 1983; Emson et al., 1985; Levant et al., 1990) implicated in the etiology of schizophrenia (Seeman, 1987). Additionally, drug-free schizophrenic patients have significantly lower concentrations of NT in their cerebrospinal fluid as compared to their age- and sex-matched controls, and upon treatment with antipsychotic drugs NT concentration returns to normal in these patients (Widerlöv et al., 1982b). Furthermore, the biochemical (e.g., increase in dopamine turnover) (Widerlöv et al., 1982a; Kalivas et al., 1983) as well as behavioral responses (e.g., decreased conditioned avoidance response, decrease in amphetamine-induced locomotion, hypothermia) (Bissette et al., 1976; Ervin et al., 1981) to centrally administered NT are reminiscent of the effects of clinically used neuroleptic drugs. In fact, these observations have led to the suggestion that NT may be an endogenous neuroleptic-like compound (Nemeroff, 1980). Neuroleptic drugs are a group of chemically diverse compounds showing an excellent correlation between their dopamine $D_{2}$ receptor-blocking efficacy and potency for antipsychotic effects (Creese et al., 1976; Seeman et al., 1976). However, NT neither binds to the $D_{2}$ receptors nor directly modulates cAMP accumulation caused by dopamine receptor agonists (Nemeroff et al., 1983). Hence, the cellular mechanism underlying the neuroleptic-like effects of NT remains unknown.

Several studies have demonstrated that administration of neuroleptic drugs increases the concentration of immunoreactive NT in striatal regions of the rat (Govoni et al., 1980; Frey et al., 1986; Letter et al., 1987; Eggerman and Zahm, 1988). Recently, we have shown that the increase in striatal peptide content following an acute single dose of haloperidol is accompanied by a dramatic increase in the neurotensin/neuromedin N (NT/N) mRNA levels (Merchant et al., 1991). Hence, halo- 
peridol-induced increases in the synthesis and possibly release of the endogenous neuroleptic NT could underlie some of the pharmacological effects of this classical antipsychotic. Haloperidol is a prototype of what have been termed "typical" antipsychotic drugs, which are known to have a high propensity to induce extrapyramidal motor side effects (EPS) in patients. Interestingly, in our initial study (Merchant et al., 1991) we found that the effects of a single acute dose of haloperidol were confined primarily to the dorsolateral region of the striatum in the rat. This region is a part of the basal ganglia circuitry implicated in regulation of motor output and is not thought to be a part of the limbic systems involved in mediating antipsychotic effects. Therefore, it raises the possibility that the haloperidol-sensitive NT neurons in the motor striatal region may be involved in mediating some of the acute EPS (e.g., dystonia, parkinsonism) caused by this drug. If true, the "atypical" antipsychotic, clozapine, which is relatively free of acute EPS (Gerlach et al., 1975), would not be expected to influence NT/N gene expression in these neurons.

In the present study, we have compared and characterized the acute effects of haloperidol and clozapine on NT/N mRNA expression using the techniques of in situ hybridization histochemistry and solution hybridization in order to understand the functions of the dorsolateral neostriatal NT cells. Additionally, we have studied the molecular mechanism underlying the increase in levels of NT/N mRNA caused by haloperidol. An increase in the content of a mature mRNA species could result from either increased transcription or posttranscriptional regulation such as an increase in mRNA stability or transport out of the nucleus (Guyette et al., 1979; Hynes et al., 1979; McKnight and Palmiter, 1979). Using an antisense RNA probe derived from an intervening sequence in the NT/N gene, we have examined the effects of haloperidol on NT/N nuclear primary transcripts as an index of changes in the rate of transcription of the gene. This approach has been used successfully to study pro-opiomelanocortin gene transcription in rat brain (Fremeau et al., 1989).

Our results demonstrate that the expression of NT/N mRNA in a subset of neurons located in the dorsolateral region of the neostriatum is differentially regulated by prototypes of typical and atypical neuroleptics (haloperidol and clozapine, respectively). On the other hand, NT/N mRNA expression in the accumbal shell was enhanced similarly by these two drugs. This raises the possibility that anatomically distinct populations of NT neurons may be involved in mediating motor side effects and antipsychotic effects of clinically used neuroleptic drugs. Additionally, the effects of haloperidol on NT/N mRNA appear to be primarily a nuclear event involving synthesis and/or turnover of NT/N primary transcripts.

\section{Materials and Methods}

Animals and drug treatment. Adult male Sprague-Dawley rats (200$250 \mathrm{gm}$; Simonsen Laboratories, Gilroy, CA) were housed two to three per cage in a temperature-controlled environment with $12 \mathrm{hr}$ light/12 $\mathrm{hr}$ dark cycle and were given free access to standard laboratory chow and water. In a pilot study, the effects of stress caused by handling and/ or an intraperitoneal injection were assessed by comparing the expression of NT/N mRNA in four separate groups of animals $(n=4)$ : injection naive but handled $30 \mathrm{~min}$ prior to death or treated with saline $(1 \mathrm{ml} / \mathrm{kg}$, i.p.) at $30 \mathrm{~min}, 1 \mathrm{hr}$, or $3 \mathrm{hr}$ prior to death. None of these groups differed in the distribution of NT/N mRNA-containing cells. To study the effects of neuroleptics on NT/N mRNA expression, animals were treated with a single intraperitoneal injection of haloperidol $(1 \mathrm{mg} /$ kg; McNcil Pharmaccuticals), clozapinc (20, 30, or $40 \mathrm{mg} / \mathrm{kg}$; Sandoz Pharmaceuticals), or vehicle $(1 \mathrm{ml} / \mathrm{kg})$. At various times after treatment, rats were killed by decapitation between 12:00 noon and 3:00 P.M. Brains were rapidly removed, frozen on dry ice, divided sagittally into two halves, and stored at $-80^{\circ} \mathrm{C}$ until processed for in situ hybridization or quantitative solution hybridization assays.

Synthesis of probes. The probe used for detection of mature NT/N mRNA was synthesized in vitro using the method of Melton et al. (1984) from a 336 base pair EcoRV/Bgl II fragment of NT cDNA (nucleotides 626-961) subcloned into BamHI/SmaI-digested pGEM4 (Promega). The specificity of this subclone (prNT4) has been established previously (Alexander et al., 1989; Merchant et al., 1991). EcoRI-linearized prNT4 was used as a template for the antisense RNA probe labeled with either ${ }^{35} \mathrm{~S}-U T P\left(0.9-1 \times 10^{8} \mathrm{dpm} / \mathrm{pmol}\right)$ for in situ hybridization or with ${ }^{32} \mathrm{P}$ UTP (4-6 $\left.\times 10^{7} \mathrm{dpm} / \mathrm{pmol}\right)$ for solution hybridization. A sense RNA transcript was synthesized from the Hind III-linearized prNT4 with trace amounts of ${ }^{3} \mathrm{H}-U T P$ for generating a standard curve in the solution hybridization assay as described below.

To generate an intron-specific subclone ( $\mathrm{pNTgHX}$ ), a unique-sequence 1.0 kilobase HindIII/XmnI fragment derived from intron 2 of the rat NT/N gene was inserted into HindIII/Smal-digested pGEM3 $\mathrm{ZF}(-)$ (Promega). Antisense intron probe for in situ hybridization was transcribed from HindIII-linearized plasmid using T7 RNA polymerase and labeled to a specific activity of $3-5 \times 10^{8} \mathrm{dpm} / \mathrm{pmol}$ with ${ }^{35} \mathrm{~S}$-UTP. A sense probe was also synthesized to the same specific activity from EcoRI-linearized plasmid using SP6 RNA polymerase. Radiolabeled nucleotides and enzymes were obtained from New England Nuclear and Boehringer Mannheim, respectively.

In situ hybridization histochemistry. A minor modification of previously described methods (Alexander et al., 1989; Merchant et al., 1991) was used. Briefly, sagittally halved brains were cut into $20-\mu$ m-thick slices, thaw mounted onto gelatin-coated slides, and stored at $-80^{\circ} \mathrm{C}$ until processed as follows. The slides were warmed to room temperature (RT) for $10 \mathrm{~min}$, fixed in $4 \% \mathrm{w} / \mathrm{v}$ paraformaldehyde, acetylated with $0.25 \% \mathrm{v} / \mathrm{v}$ acetic anhydride in $0.1 \mathrm{M}$ triethanolamine $(\mathrm{pH} 8.0$ ), dehydrated through a graded series of ethanol, delipidated in chloroform, rehydrated to $95 \%$ v/v ethanol, and air dried. Adjacent sections were used to hybridize with either the coding region- or the intron-specific probes described above. The labeled probe was applied at a saturating concentration $(1.5-2 \mathrm{pmol} / \mathrm{ml})$ in a hybridization solution [ $10 \mathrm{~mm}$ Tris$\mathrm{HCl}$ buffer, $\mathrm{pH} 8.0$, containing $50 \% \mathrm{v} / \mathrm{v}$ deionized formamide, $0.3 \mathrm{M}$ $\mathrm{NaCl}, 1 \mathrm{~mm}$ EDTA, 10\% w/v dextran sulfate, $1 \times$ Denhardt's solution (Sambrook et al., 1989), $10 \mathrm{~mm}$ dithiothreitol, and $0.5 \mathrm{mg} / \mathrm{ml}$ yeast $t$ RNA]. Sections were covered with siliconized coverslips, and the slides were incubated for $16-18 \mathrm{hr}$ in a humid chamber at $20^{\circ} \mathrm{C}$ below the calculated melting temperature $\left(53^{\circ} \mathrm{C}\right.$ for the coding region-specific probe and $50^{\circ} \mathrm{C}$ for the intron-specific probe). The coverslips were removed in $1 \times \mathrm{SSC}(0.15 \mathrm{M} \mathrm{NaCl}+0.015 \mathrm{M}$ sodium citrate, $\mathrm{pH} 7.0)$, and the slides were washed in $1 \times$ SSC for $30 \mathrm{~min}$ at RT. This low-stringency wash was followed by RNase treatment [ $20 \mu \mathrm{g} / \mathrm{ml}$ RNase A in a buffer containing $10 \mathrm{~mm}$ Tris- $\mathrm{HCl}$ (pH 7.4), $0.5 \mathrm{~m}$ EDTA and $0.5 \mathrm{M} \mathrm{NaCl}$ ] at $37^{\circ} \mathrm{C}$ for $30-45 \mathrm{~min}$. The slides were then rinsed in the buffer used for RNase treatment at $37^{\circ} \mathrm{C}$ for $30 \mathrm{~min}$ followed by three high-stringency washes ( $20 \mathrm{~min}$ each) in $0.1 \times \mathrm{SSC}$ at $15^{\circ} \mathrm{C}$ below the theoretical melting temperature $\left(52^{\circ} \mathrm{C}\right.$ for the coding sequence-specific probe and $50^{\circ} \mathrm{C}$ for the intron-specific probe). The slides were subsequently dehydrated through a graded alcohol series in which water was substituted by 0.6 $M$ ammonium acetate and air dried.

To determine the specificity of the intron-specific probe, some sections were treated as described above except labeled sense probe of the same specific activity was substituted for labeled antisense probe.

Autoradiography. For film autoradiography following hybridization with the coding region probe, slides were apposed to Hyperfilm- $\beta$ max (Amersham) for 2-3 d and films were developed in Kodak D-19 solution. Slides were then dipped in Kodak NTB2 nuclear tract emulsion diluted $1: 1$ with $0.6 \mathrm{M}$ ammonium acetate, air dried in the dark for 2 $\mathrm{hr}$, and exposed for either $6 \mathrm{~d}$ (for the coding region probe) or $15 \mathrm{~d}$ (for the intron-specific probe). The emulsion was developed in D-19 diluted $1: 1$ with water. Sections were counterstained in $0.1 \% \mathrm{w} / \mathrm{v}$ cresyl violet acetate, dehydrated, and coverslipped with Permount. Brain sections from different groups were anatomically matched according to the atlas of Paxinos and Watson (1986) using bright-field microscopy prior to examination of the distribution of autoradiographic grains in dark field. Quantification of hybridization signal from film autoradiograms was carried out by a person blind to the experimental design. Autoradio- 

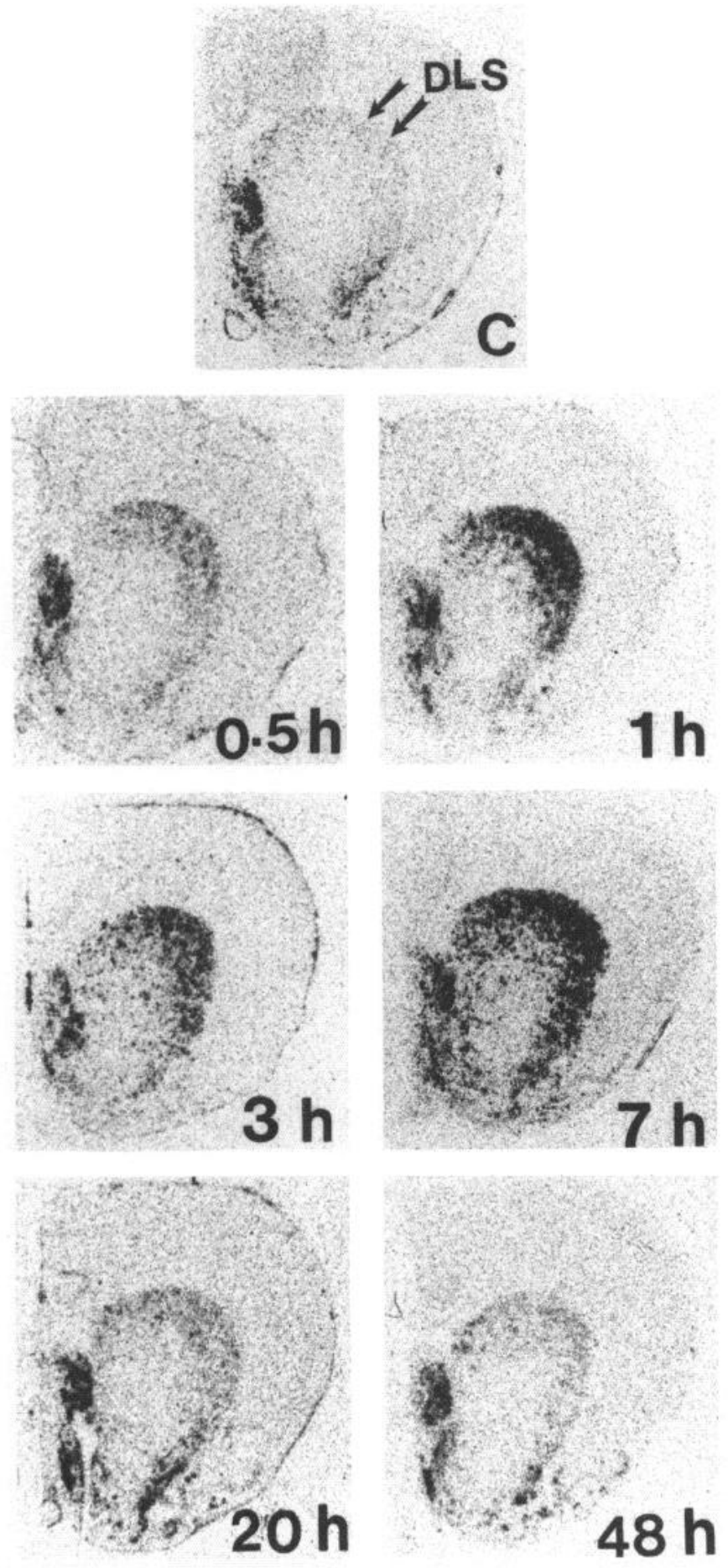

Figure 1. Film autoradiograms showing the time course of haloperidol-induced increase in NT/N mRNA-expressing cells. Animals $(n=$ 6) were given a single dose of haloperidol $(1 \mathrm{mg} / \mathrm{kg}$, i.p.) and killed at $0.5,1,3,7,20$, or $48 \mathrm{hr}$ following treatment. The distribution of NT/N mRNA-expressing cells was studied using $20 \mu \mathrm{m}$ sections from the sagittally halved brain of each animal by in situ hybridization with a ${ }^{35} \mathrm{~S}$-labeled antisense RNA probe (prNT4) derived from the coding region of the NT/N gene. Film autoradiograms were generated by apposing sections to Hyperfil- $B \max$ for $48 \mathrm{hr}$. Sections at a single level of the striatum (bregma $1 \mathrm{~mm}$ ) are shown. Arrows indicate dorsolateral striatum $(D L S)$, the area most affected by haloperidol treatment. $C$, control; $h$, hr. grams were digitized with a Drexel's Unix-based Microcomputer Image Analysis System. Background optical density was subtracted from each image. Optical densities in the shell region of the nucleus accumbens (see Fig. 5) were determined at a single level (bregma $2.2 \mathrm{~mm}$ ) from four different sections per animal. For the dorsolateral striatum, the optical densities were determined using four sections from each animal at the coronal plane $1 \mathrm{~mm}$ anterior from the bregma.

Solution hybridization. This technique has recently been adapted in our laboratory from the methods of Paul et al. (1988) and is found to detect small amounts $(0.5 \mathrm{pg} /$ tube $)$ of NT/N mRNA satisfactorily in tissue extracts. Brains were cut into $300-\mu \mathrm{m}$-thick slices. The dorsolateral striatum and the nucleus accumbens (encompassing both core and shell) were microdissected on a cold plate maintained at $-10^{\circ} \mathrm{C}$ using the atlas of Palkovits and Brownstein (1988). The dorsolateral neostriatum was excised using a knife from atlas levels: A3000 $\mu \mathrm{m}$ to A300 $\mu \mathrm{m}$. Striata from two to three animals were pooled for each assay. The nucleus accumbens was dissected using a $200 \mu \mathrm{m}$ punch, and due to small amounts of the tissue, punches from all animals were pooled. Tissues were homogenized and total RNA was extracted as described previously (Chomczynski and Sacchi, 1987). Sense (with ${ }^{3} \mathrm{H}$ tracer) and antisense (with ${ }^{32} \mathrm{P}$ label) RNA transcripts from the prNT4 subclone were synthesized and purified as described above. A standard curve was generated by hybridizing increasing amounts $(0.5-200 \mathrm{pg})$ of the sense transcript with a fixed amount ( $50 \mathrm{pg} ; 20,000-30,000 \mathrm{dpm})$ of the antisense probe in hybridization buffer $(0.3 \mathrm{~m} \mathrm{NaCl}, 4 \mathrm{~mm}$ EDTA, $40 \%$ formamide, $0.2 \mathrm{mg} / \mathrm{ml}$ yeast $t \mathrm{RNA}$, and $20 \mathrm{~mm}$ Tris- $\mathrm{HCl}, \mathrm{pH} 7.4$ ). Two different concentrations of the total RNA extracted from the tissues were hybridized with the same amount of antisense RNA probe at $60^{\circ} \mathrm{C}$ for 16-18 hr. Following hybridization, samples were mixed with $1 \mathrm{ml}$ of RNase buffer containing $25 \mu \mathrm{g} / \mathrm{ml}$ RNase A and $500 \mathrm{U} / \mathrm{ml}$ RNase $\mathrm{T} 1$ and digested for $90 \mathrm{~min}$ at $37^{\circ} \mathrm{C}$. Nuclease digestion was terminated by addition of $100 \mu \mathrm{l}$ of $100 \%$ chilled trichloroacetic acid. Samples were incubated on ice for $20 \mathrm{~min}$, filtered through prewetted nitrocellulose filters, dried, and counted in scintillation fluid. The amount of NT/N mRNA per mg of total RNA for each sample was calculated using the standard curve.

Statistics. Alterations in NT/N mRNA concentrations in the dorsolateral striatum and the nucleus accumbens were quantified by solution hybridization or densitometric analysis of the film autoradiograms as described above. Data are presented as mean \pm SEM. Differences between means were analyzed using ANOVA. Following a significant difference in the variance, Scheffe's test was applied to identify groups differing significantly from control values. Differences were considered significant if the probability that they were zero was less than $5 \%$.

\section{Results}

Characterization of acute effects of haloperidol on mature $N T / N m R N A$. Expression of NT/N mRNA was examined at various times following the administration of a single dose of haloperidol ( $1 \mathrm{mg} / \mathrm{kg}$, i.p.) using a coding region antisense RNA probe for in situ hybridization. As can be seen in Figure 1, haloperidol increased NT/N mRNA expression predominantly in the dorsolateral region of the neostriatum within $30 \mathrm{~min}$ (the earliest time point examined). Maximal expression of $\mathrm{NT} / \mathrm{N}$ mRNA was observed between 3 and $7 \mathrm{hr}$ after drug administration, followed by a significant decline at $20 \mathrm{hr}$, and the expression returned to control levels by $48 \mathrm{hr}$ following haloperidol treatment. Although the largest increases were observed in the dorsolateral striatum, small increases in NT/N mRNA-expressing cells were detected in the nucleus accumbens, particularly in the shell sector of the nucleus accumbens (Figs. 2, 3) at 3 and $7 \mathrm{hr}$ after treatment. These increases were apparent even though the basal expression of NT/N mRNA in the nucleus accumbens in control rats was much higher than that in the caudate-putamen. The increased expression of NT/N gene in the dorsolateral striatum or the nucleus accumbens was not an effect of injection-related stress as determined in a pilot study (see animals and drug treatment under Materials and Methods). Significant hybridization to NT/N mRNA in control rats was also 

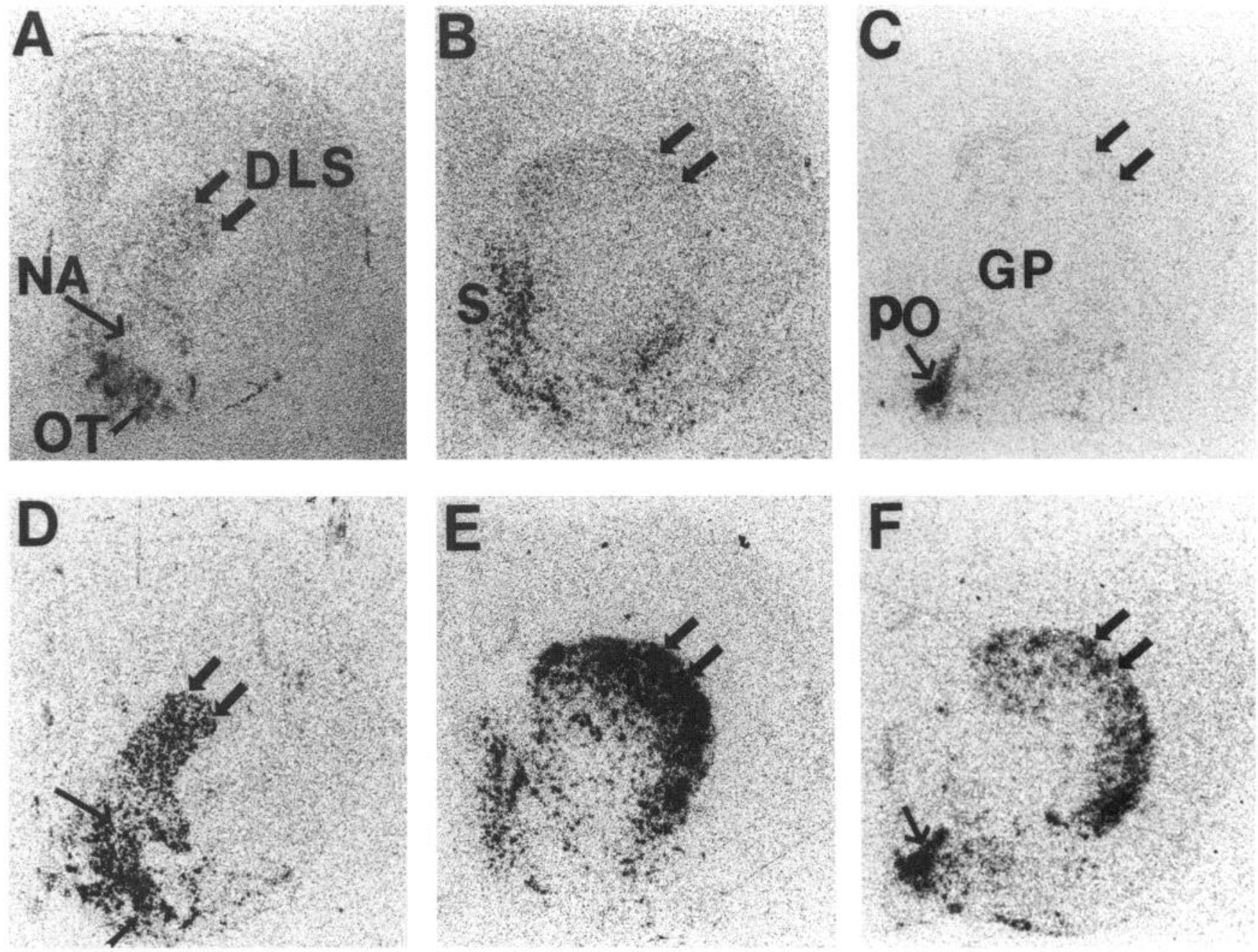

Figure 2. Distribution of NT/N mRNA-containing cells at the peak of the haloperidol effect. Film autoradiograms from the study described in Figure 1 are shown at three different rostral-caudal levels of the striatum. $A$ (bregma $2.2 \mathrm{~mm}$ ), $B$ (bregma $0.7 \mathrm{~mm}$ ), and $C$ (bregma $-0.8 \mathrm{~mm})$ are representative sections from saline-treated animals, whereas $D, E$, and $F$ are anatomically matched typical sections from animals killed at 7 hr following haloperidol. Arrows indicate hybridization signal in dorsolateral striatum $(D L S)$, nucleus accumbens $(N A)$, olfactory tubercle $(O T)$, and preoptic region $(P O)$. $S$, Septal nuclei; $G P$, globus pallidus.

observed in several other areas such as the septal nuclei, olfactory tubercle, piriform cortex, and the preoptic region of the hypothalamus. However, haloperidol did not appear to alter NT/N mRNA levels in these regions (Fig. 2).

To quantitate the haloperidol-induced increases in NT/N mRNA levels in the dorsolateral striatum, this region was microdissected from the contralateral brain of animals used for the in situ hybridization study described above and the content of NT/N mRNA was determined by quantitative solution hybridization. In concordance with the in situ assay, NT/N mRNA levels were increased time dependently by haloperidol (Fig. 4). The maximal increases were observed at $7 \mathrm{hr}$ following drug administration, at which time NT/N mRNA content in the dorsolateral striatum was approximately an order of magnitude higher than the control levels. Haloperidol effects on NT/N mRNA expression in the shell of nucleus accumbens were quantified by densitometric analysis of the film autoradiograms. Hybridization to NT/N mRNA in the nucleus accumbens shell significantly increased at 3 and $7 \mathrm{hr}$ following haloperidol (Fig. $5 A$ ) and subsequently declined to control levels by $20 \mathrm{hr}$ after drug treatment. The haloperidol effect in the nucleus accumbens was also evident in a $45 \%$ increase in NT/N mRNA content determined by solution hybridization using a pool of punches encompassing both the shell and the core of the nucleus accumbens dissected from the contralateral hemisected brains of same animals (Fig. $5 B$ ).

Effects of clozapine on mature NT/N mRNA expression. Unlike haloperidol, a single dose of clozapine $(20 \mathrm{mg} / \mathrm{kg}$, i.p. $)$ did not appear to affect the number of NT/N mRNA-expressing cells significantly in the dorsolateral striatum at $1 \mathrm{hr}, 3 \mathrm{hr}$, or 7 $\mathrm{hr}$ following treatment (Fig. 6). Examination of emulsion-coated slides under dark field revealed a few hybridization-positive cells in the caudate-putamen at 1 and $3 \mathrm{hr}$ after treatment. However, these cells were not tightly localized in the dorsolateral region as seen with haloperidol but were scattered unevenly in the dorsal striatum. Thus, following a single administration of 20 $\mathrm{mg} / \mathrm{kg}$ of clozapine, the amount of NT/N mRNA in three separate pools of total RNA from dorsolateral caudate did not increase over control level at any of the time points examined (Fig. 4). A subsequent dose-response study revealed that even 

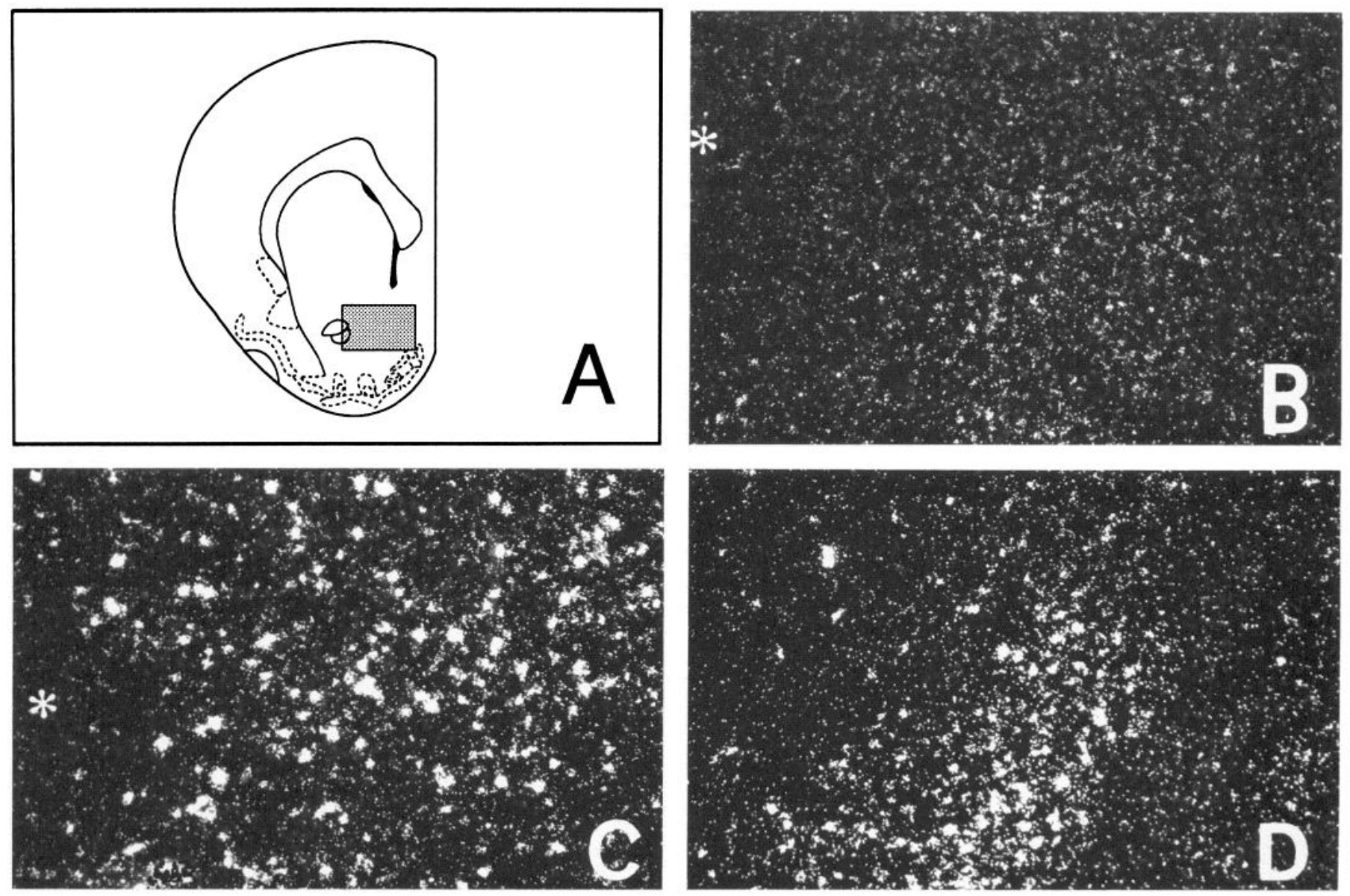

Figure 3. Effects of haloperidol and clozapine on NT/N mRNA expression in the nucleus accumbens. Rats were treated with a single dose of haloperidol $(1 \mathrm{mg} / \mathrm{kg})$, clozapine $(20 \mathrm{mg} / \mathrm{kg})$, or vehicle $(1 \mathrm{ml} / \mathrm{kg})$. In situ hybridization was carried out using the coding region probe as described in Figure 1. Autoradiograms were generated after 6-7 d exposure to Kodak NTB2 emulsion. $B-D$ are low-magnification, dark-field photomicrographs through the nucleus accumbens and represent the region of the brain schematically shown in $A$ by the shaded rectangle. The photomicrographs represent typical hybridization in a control section $(B)$, or from rats treated with haloperidol for $7 \mathrm{hr}(C)$ or clozapine for $3 \mathrm{hr}(D)$. Clusters of silver grains represent cells expressing NT/N mRNA. * Indicates anterior commisure.

at $30 \mathrm{mg} / \mathrm{kg}$ (i.p.), clozapine remained ineffective in inducing NT/N mRNA expression in the dorsolateral striatum (Fig. 7). However, at $40 \mathrm{mg} / \mathrm{kg}$, an apparently toxic dose at which one out of five animals in the group died, a significant increase in hybridization signal in the dorsolateral striatum was observed.

In contrast to the caudate-putamen, $3 \mathrm{hr}$ following $20 \mathrm{mg} / \mathrm{kg}$ of clozapine, a significantly higher expression of NT/N mRNA was observed in the nucleus accumbens (Figs. 3,6). As with haloperidol, this effect was predominantly observed in the shell sector. Quantitative analysis of film autoradiograms indicated a significant increase in the optical density in the accumbal shell following clozapine (Fig. 5A). Solution hybridization using total RNA pooled from the entire nucleus accumbens reflected this clozapine-induced increase in NT/N mRNA content (Fig. $5 B$ ), which was comparable in magnitude to that observed with haloperidol.

Haloperidol increases nuclear levels of intron-containing $N T / N$ primary transcripts. An antisense RNA transcribed from a nonrepetitive, intronic sequence of NT genomic DNA (pNTgHX; Fig. 8) was used to study the distribution of cells containing NT/N primary transcripts following treatment with saline or haloperidol. The specificity of this probe for nuclear primary transcripts was tested by comparing the cellular distri- bution of autoradiographic grains generated by this probe with those produced by hybridization to the coding region probe. The grains following hybridization with the intron-specific probe showed compact localization predominantly over the nuclei of neurons, whereas those generated by the coding region probe were scattered around the cytoplasmic portion of the hybridization-positive cells (Fig. 9). Additionally, no specific hybridization was observed when a sense RNA probe synthesized to the same specific activity was employed (Fig. 9C). In situ hybridization with the antisense intron sequence probe to brain sections adjacent to those used to study the distribution of mature NT/N mRNA did not show any specific hybridization in the dorsolateral striatum of saline-treated rats (Fig. 10A). At 30 min following haloperidol, an increase in the number of cells expressing intron-containing NT/N transcripts was evident in the dorsolateral caudate (Fig. 10B). A further increase in hybridization to the nuclear transcripts was observed by $1 \mathrm{hr}$ after haloperidol (Fig. 10C), but by $3 \mathrm{hr}$, hybridization-positive cells were no longer apparent in this region (Fig. 10D). No hybridization was observed at subsequent time points $(7,20,48 \mathrm{hr})$ in the dorsolateral caudate-putamen (data not shown). Following haloperidol, cells at their peak expression of intron-containing NT/N transcripts (detected by the intron probe) ap- 


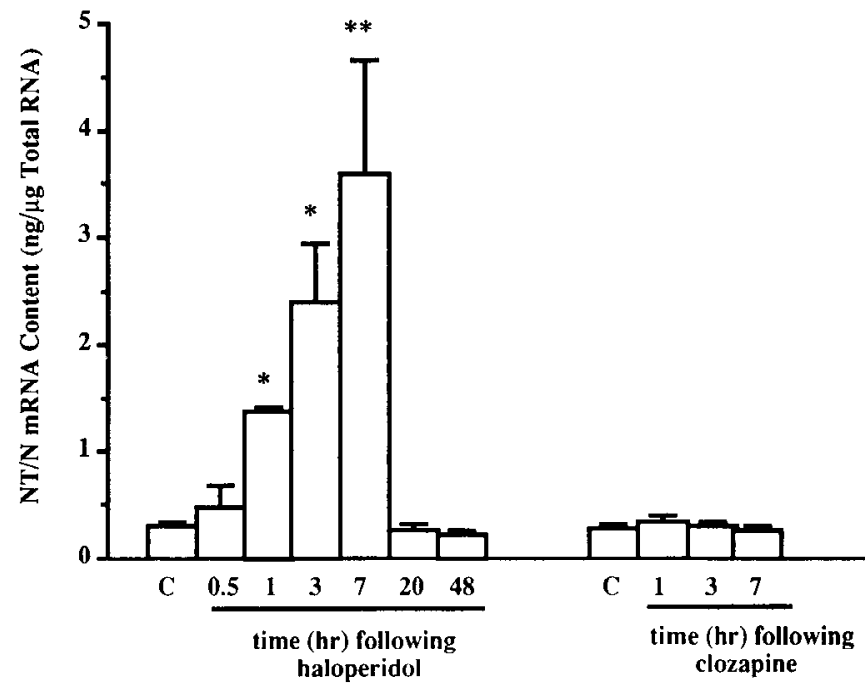

Figure 4. Quantification of the effects of antipsychotic drug treatment on dorsolateral striatal NT/N mRNA expression. Dorsolateral striatum was microdissected from the contralateral brains of the animals used for in situ hybridization analysis. Levels of NT/N mRNA were determined by solution hybridization using a ${ }^{32} \mathrm{P}$-labeled, antisense coding region probe (prNT4). Each bar represents mean NT mRNA content \pm SEM in two (haloperidol) or three (clozapine) separate pools of total RNA. ${ }^{*}, P<0.05,{ }^{* *}, P<0.001$ when compared to the saline-treated control $(C)$.

peared to have the same anatomical localization as that observed with cells expressing mature NT/N mRNA (detected using the coding region probe) (Fig. 11).

\section{Discussion}

The present study clearly demonstrates that the typical and atypical antipsychotics, haloperidol and clozapine, respectively, differentially affect discrete NT neuronal populations in the neostriatum of the rat. The level of mature NT/N mRNA in the dorsolateral region of the striatum was significantly and time dependently increased by a single dose of haloperidol but not by nontoxic doses of clozapine (Figs, 1, 4, 6, 7). To our knowledge, this is the first report indicating that acute treatment with typical and atypical antipsychotics differentially affects NT/N mRNA expression in a distinct population of striatal neurons. The results presented here also demonstrate for the first time that the predominant molecular site of action of haloperidol on striatal NT systems appears to be the nucleus of cells expressing this peptide since the increase in mature mRNA caused by haloperidol was preceded by an increase in nuclear levels of intron-containing NT/N primary transcripts.

An extremely rapid increase (within $30 \mathrm{~min}$ ) in the expression of mature NT/N mRNA in the dorsolateral striatum was evident following a single dose of haloperidol (Fig. 1). Additionally, the magnitude of this induction was quite dramatic as evident by the observation that at the peak occurring between 3 and $7 \mathrm{hr}$ after treatment, NT/N mRNA levels were an order of magnitude higher than those observed in control rats (Figs. 1, 4). The rapid effect of haloperidol on NT/N mRNA levels suggests that it may be a direct consequence of the blockade of dopamine $\mathrm{D}_{2}$ receptors on striatal NT cells. Supporting this, striatal intrinsic neurons have been demonstrated to express $\mathrm{D}_{2}$ receptors (Meador-Woodruff et al., 1989; Gerfen et al., 1990). However, an
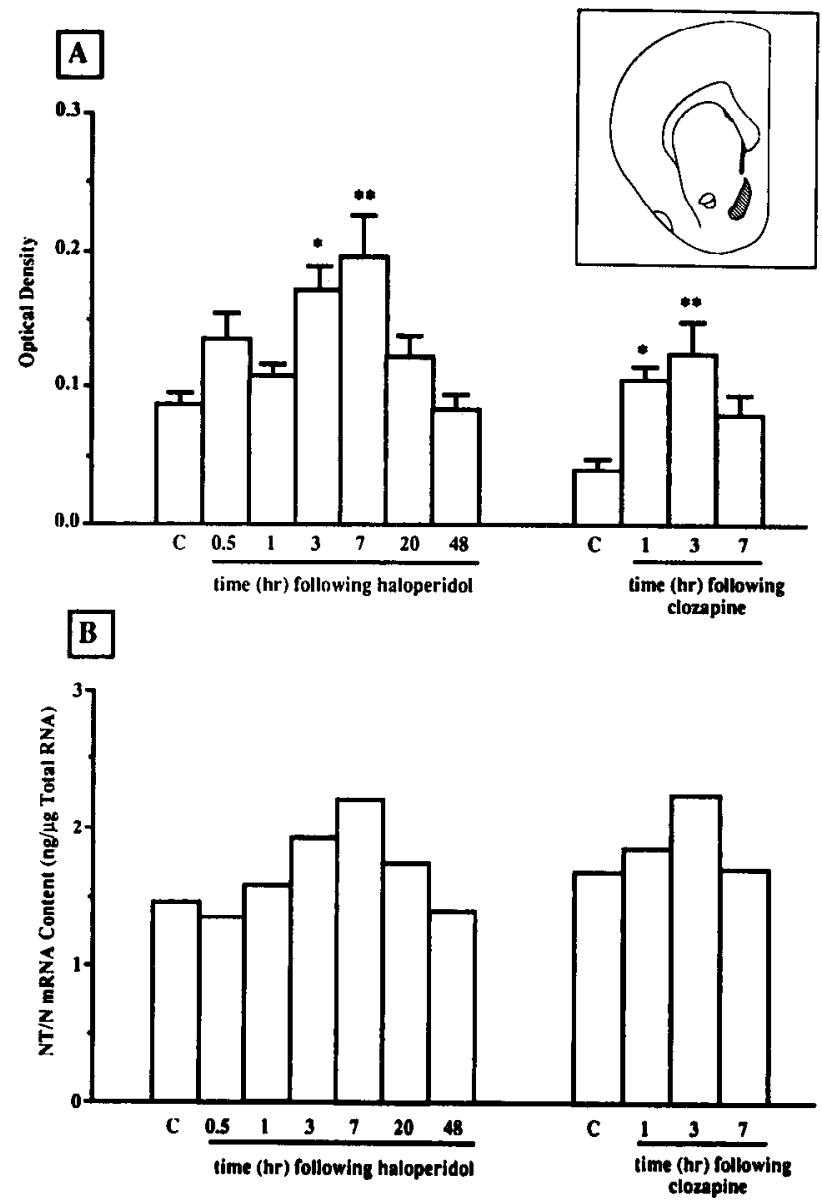

Figure 5. Quantification of the effects of antipsychotic drugs on NT/N mRNA expression in the nucleus accumbens. Animals were treated as described in Figures 1 and 3. A, In situ hybridization was carried out using the ${ }^{35}$ S-labeled coding region probe (prNT4) as described in Figure 1. Film autoradiograms were generated, and background-subtracted optical densities in the shell sector of the nucleus accumbens were determined using a computer-assisted image analysis system. The inset schematically shows the region of the nucleus accumbens sampled from each brain section. Each bar represents mean optical density \pm SEM $(n=6$ for each group). ${ }^{*}, P<0.05,{ }^{* *}, P<0.001$ when compared to the salinetreated control $(C)$. $B$, Antipsychotic induction of NT/N mRNA was also studied by solution hybridization as described in Figure 4. Nucleus accumbens punches from the contralateral brains of animals used for the in situ hybridization analysis were used. Each bar represents the NT/N mRNA level in a single pool of total RNA.

involvement of other intervening systems in haloperidol action on NT/N mRNA expression is also possible.

The function(s) of the dorsolateral striatal NT neurons that are influenced by haloperidol remains unknown. However, because of its extrapyramidal connections, the dorsolateral striatum may be involved in regulation of basal ganglia motor output. Acute induction of NT/N mRNA expression in this region by haloperidol suggests that these NT neurons may be involved in motor effects (e.g., catalepsy) of this drug in rats. This contention is supported by the observation that nontoxic doses of the atypical antipsychotic clozapine, which do not cause catalepsy, did not significantly affect NT/N mRNA levels in the dorsolateral striatum (Figs. 4, 6, 7). Cataleptic effects of neuroleptic drugs have generally been attributed to blockade of dopamine receptors in the nigroneostriatal pathway (Carlsson, 1967). Several studies have also indicated a positive correlation 
Figure 6. Film autoradiograms showing the effects of clozapine on distribution of NT/N mRNA-expressing cells in the striatum. Rats $(n=6)$ were treated with a single injection of clozapine $(20 \mathrm{mg} / \mathrm{kg}$, i.p.) or vehicle and killed at 1,3 , or $7 \mathrm{hr}$ after the treatment. In situ hybridization was carried out as described in Figure 1. Autoradiograms represent $72 \mathrm{hr}$ of exposure to Hyperfilm- $B$ max. Typical sections are shown at the same level (bregma $1 \mathrm{~mm}$ ) of the striatum. $\mathrm{C}$, Control; $\mathrm{Cl}$, clozapine. Double arrows point at the hybridization signal in the dorsolateral striatum (DLS), and a single arrow indicates hybridization in the nucleus accumbens $(N A)$.
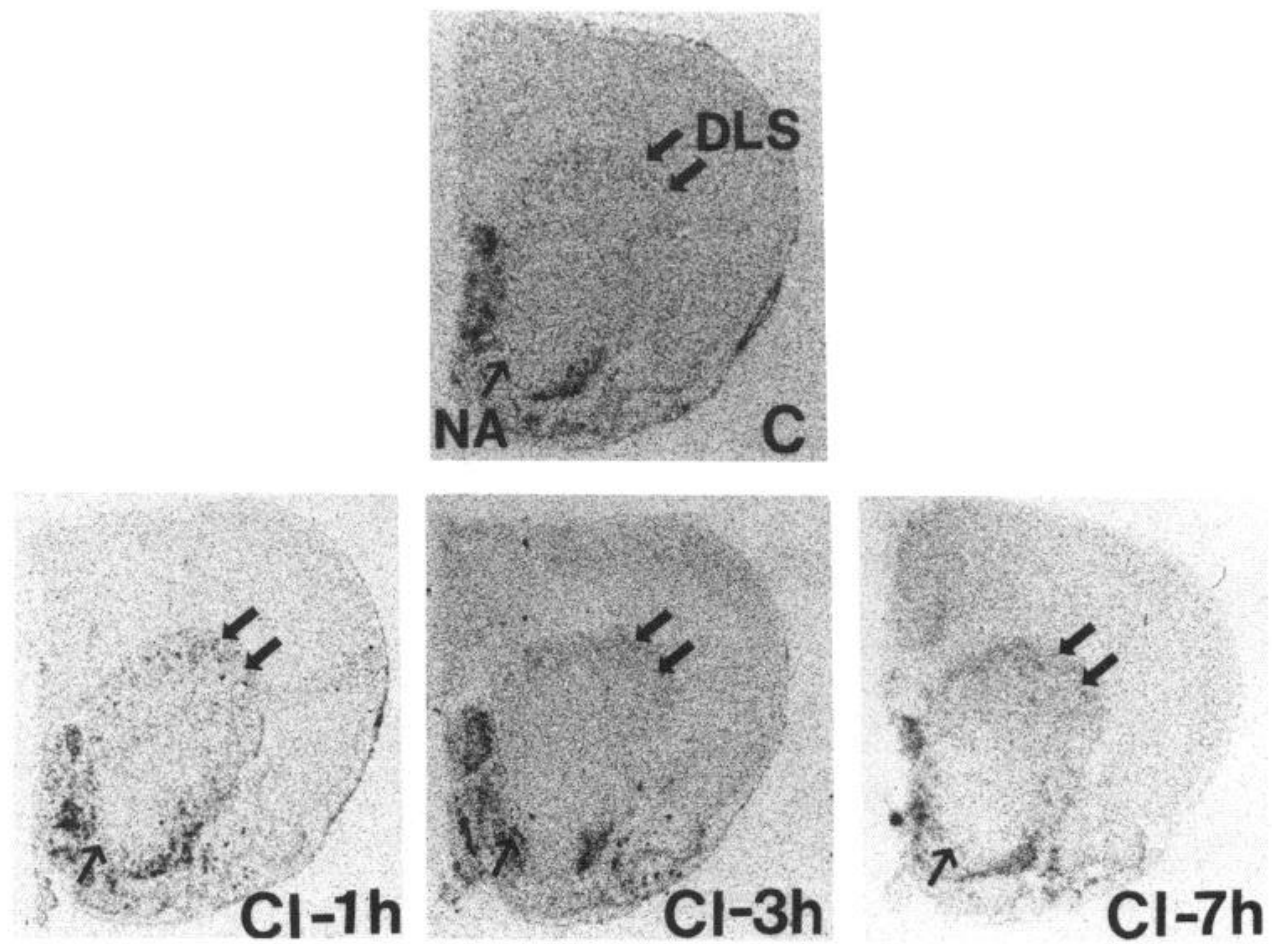

between the potency of antipsychotic drugs to induce catalepsy in rats and acute production of EPS in humans. Hence, it is tempting to speculate that the response of discrete NT neurons in the caudate-putamen to antipsychotics may be used as a screening assay to predict their liability to induce acute EPS (such as dystonia, parkinsonism) in humans. In this regard, it is important to note that cholecystokinin and enkephalin peptides that also closely interact with central dopamine systems are not differentially affected by typical and atypical antipsychotics (Frey, 1983; Angulo et al., 1990). However, further studies with a variety of typical and atypical antipsychotic drugs are required in order to understand the potential role of various NT neuronal populations in mediating specific pharmacological effects of these drugs.

In contrast to the caudate nucleus, NT/N mRNA expression in the nucleus accumbens shell was increased following treatment with both haloperidol and clozapine, although the magnitude of this increase was much smaller than that observed in the dorsolateral caudate (Figs. 3, 5). Additionally, haloperidolinduced increases in the nucleus accumbens occurred after a longer lag time than in the caudate-putamen (Figs. 4, 5). These data are consistent with the observation that increases in immunoreactive NT content of the nucleus accumbens caused by haloperidol occur later and are of smaller magnitude than those occurring in the caudate-putamen (Frey et al., 1986; Letter et al., 1987; Merchant et al., 1988a). The longer lag time also explains why we previously failed to observe a significant increase in NT/N mRNA content in the nucleus accumbens $1 \mathrm{hr}$ after haloperidol treatment (Merchant et al., 1991). In contrast to the present study, Williams et al. (1990) observed larger increases in NT/N mRNA expression in the nucleus accumbens and the ventral striatum following two doses of haloperidol (2 $\mathrm{mg} / \mathrm{kg}$, i.p.) 17 and $10 \mathrm{hr}$ prior to death. Additionally, this dosing regimen did not appear to increase NT/N mRNA expression in the dorsolateral striatum. Thus, distinct populations of NT neurons appear to be differentially regulated in response to single or multiple doses of haloperidol and/or the recovery time allowed following drug treatment. Supporting this, we have observed that at $18 \mathrm{hr}$ following three doses of haloperidol $(6 \mathrm{hr}$ intervals) there is a selective increase in the number of NT/N mRNA-expressing cells in the nucleus accumbens and ventral caudate-putamen but not in the dorsal striatum (K. M. Merchant, D. M. Dorsa, unpublished observations). It is likely that maximal induction in NT/N mRNA in the ventral striatum (including the nucleus accumbens) requires multiple stimuli and/ or a longer lag time.

Both haloperidol and clozapine caused similar increases in NT/N mRNA expression in the nucleus accumbens, predominantly in the shell sector. Recent anatomical and biochemical data indicate that whereas the core of the nucleus accumbens may be associated with the nigrostriatal dopamine system, the shell may be related to the mesolimbic system (Zahm, 1989; Deutch and Cameron, 1991; Heimer et al., 1991). Thus, increased expression of NT/N gene in the limbic structure by the two prototypes of typical and atypical antipsychotic drugs raises the possibility that the shell NT neurons may represent a pathway involved in some of the common pharmacological effects of these two classes of drugs. Whether it involves manifestation of antipsychotic effects in humans remains to be determined.

The selective increase in NT/N mRNA content in the limbic striatum induced by clozapine is consistent with its preferential effects on mesolimbic rather than mesostriatal dopamine systems (Chiodo and Bunney, 1983; White and Wang, 1983). Additionally, following chronic treatment with clozapine, an increase in immunoreactive NT content is observed in the nucleus accumbens but not in the dorsolateral striatum (Kilts et al., 


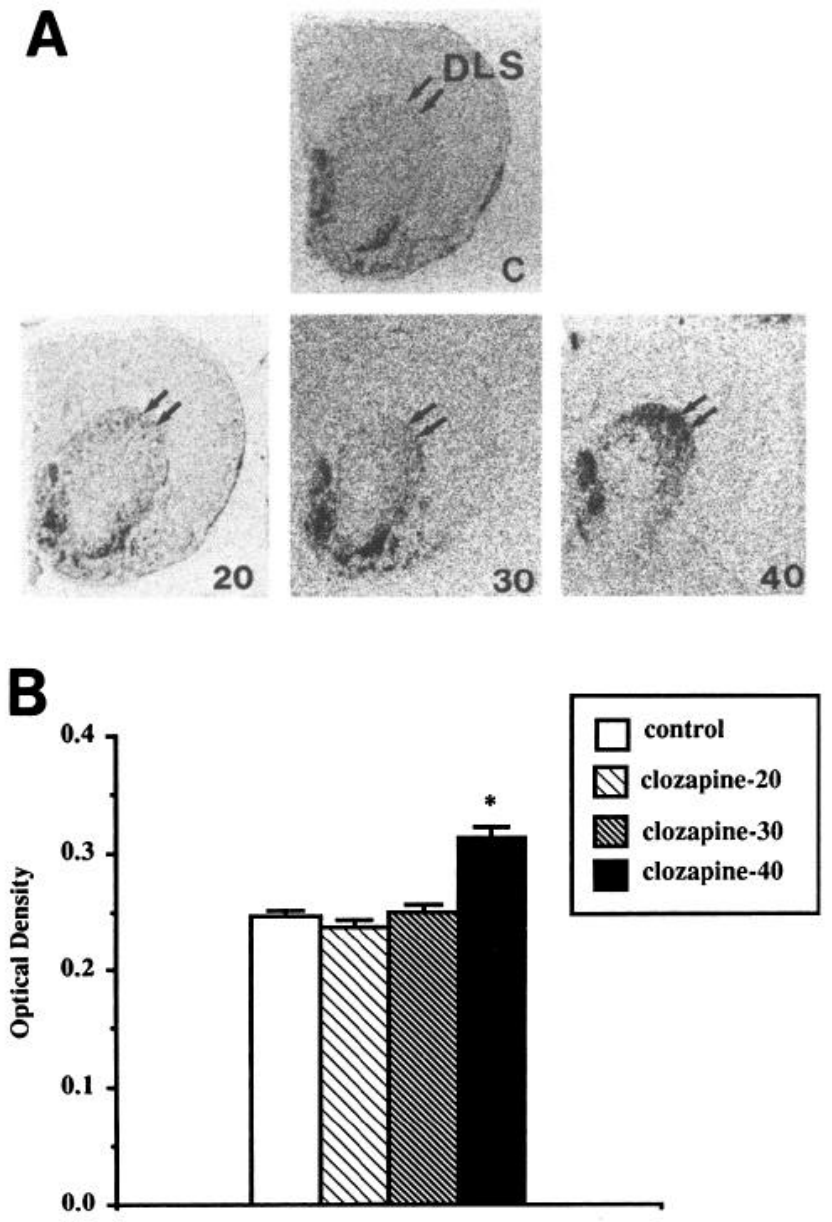

Figure 7. Dose-response study for the effects of clozapine on NT/N mRNA expression in the dorsolateral striatum. Rats were treated intraperitonially with a single dose of 20,30 , or $40 \mathrm{mg} / \mathrm{kg}$ of clozapine 1 $\mathrm{hr}$ prior to death. In situ hybridization was carried out as described in Figure 1. $A$, Film autoradiograms at a single level through the striatum (bregma $1 \mathrm{~mm}$ ) are shown from a control rat $(C)$ or animals treated with various doses of clozapine (numbers represent the dose of clozapine in $\mathrm{mg} / \mathrm{kg}$, i.p.). Arrow indicates hybridization signal in the dorsolateral striatum $(D L S)$. B, Quantification of hybridization signal in the dorsolateral striatum was carried out by densitometric analysis. Each bar represents mean optical density $\pm \operatorname{SEM}(n=5$, except in clozapine-40 group, where $n=4){ }^{*}, P<0.02$ when compared to all other groups.

1988). The precise cellular mechanism underlying clozapine's selectivity for the mesolimbic systems is not clear. It is possible that clozapine's ability to block receptors other than dopamine $\mathrm{D}_{2}$ (e.g., muscarinic, $\alpha_{1}$ noradrenergic, $5-\mathrm{HT}_{2}$ ) renders it more selective for the limbic pathways compared to the mesostriatal pathways. The responses of striatal NT neurons to concurrent administration of haloperidol and the antimuscarinic drug trihexyphenidyl, for example, would therefore be interesting especially in view of the clinical observation that coadministration of this anticholinergic drug with typical neuroleptics reduces the incidence of EPS (Fann and Lake, 1976; McEvoy, 1983). Recent identification and cloning of a novel dopamine receptor, termed $D_{4}$, which appears to be more sensitive to clozapine than $D_{2}$ receptors (Van Tol et al., 1991), also raises the possibility that the selectivity of clozapine may be attributed to its preferential

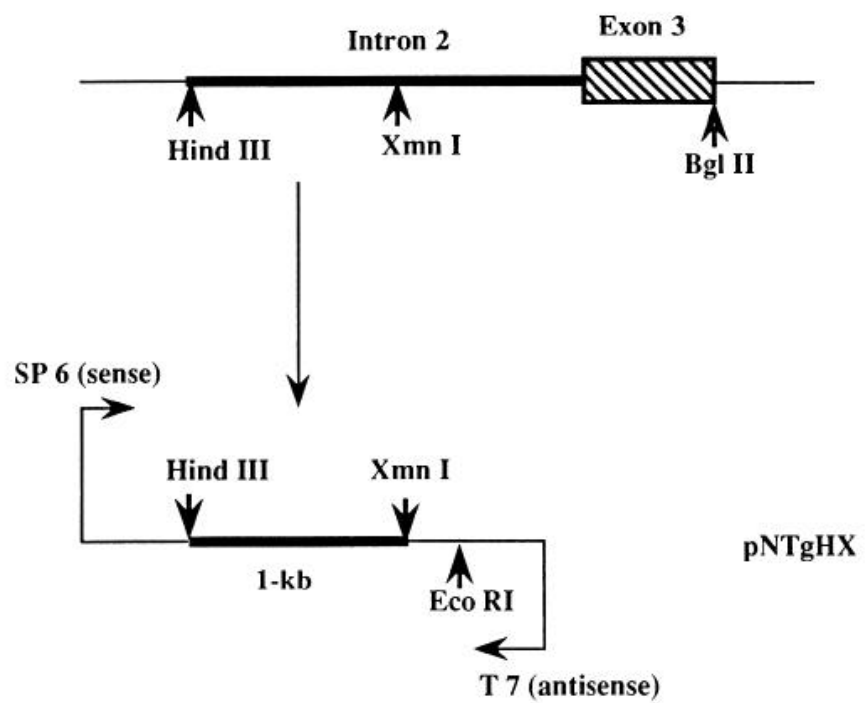

Figure 8. Schematic diagram of the subcloning strategy used to generate the intron-specific probe. Plasmid sequences (-), intron sequences (-), and exon sequences (rectangle with diagonal lines) are shown.

blockade of $\mathrm{D}_{4}$ receptors. Further characterization of the distribution of $\mathrm{D}_{4}$ receptors will help identify specific brain structures targeted by this atypical antipsychotic.

The projection fields of the distinct populations of striatal NT neurons remain conjectural. It is likely that the dorsolateral striatal NT neurons project to the globus pallidus and/or substantia nigra, the two major structures that receive striatal motor output. Gerfen et al. (1990) have recently demonstrated that $\mathrm{D}_{2}$ receptors appear to be functionally associated with striatal neurons that project to the globus pallidus whereas $D_{1}$ receptors are primarily associated with striatal-nigral pathways. In view of this, it is likely that the haloperidol-sensitive NT neurons in the dorsolateral striatum project to the globus pallidus. Supporting this, an increase in NT-immunoreactive fibers and terminals is observed in the globus pallidus following treatment with haloperidol (Eggerman and Zahm, 1988). Studies are underway to map the projection fields of striatal NT neurons. Such studies should advance further our understanding of the functions of these distinct NT neuronal populations.

In order to understand the molecular mechanism underlying haloperidol induction of NT/N mRNA, the effects of this drug on NT/N primary transcripts were examined. The use of an intron-specific probe for in situ hybridization analysis revealed that the levels of intron-containing NT/N gene transcripts were rapidly, but transiently, elevated in the dorsolateral striatum after a single dose of haloperidol (Fig. 10). The transient accumulation of intron-containing transcripts indicates that haloperidol treatment results in the activation of NT/N gene transcription, although possible effects on stability of NT/N precursor RNA cannot be ruled out at present. The anatomical distribution of cells labeled by the intron and exon probes was identical (Fig. 11). Additionally, maximal induction of the introncontaining transcripts (observed at $1 \mathrm{hr}$; Fig. 10) preceded the maximal induction in the mature mRNA (observed at $7 \mathrm{hr}$; Figs. 1, 4). These data suggest that the rapid, transient activation of NT/N gene transcription was responsible for the subsequent 


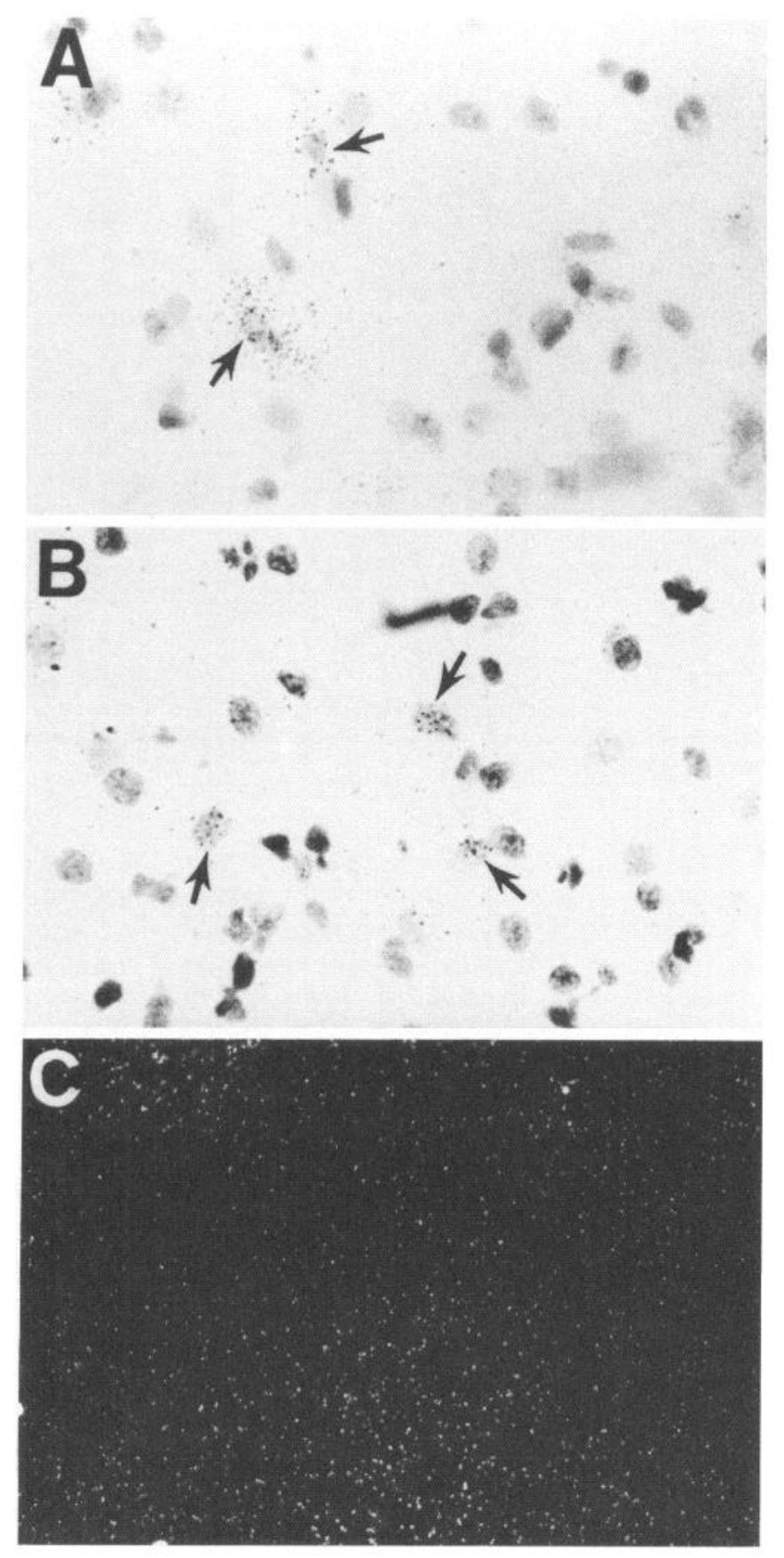

Figure 9. Specificity of the intron-derived probe (pNTgHX) for NT/N transcripts. High-magnification, bright-field photomicrographs of autoradiograms through the dorsolateral striatum of haloperidol-treated animals are shown following in situ hybridization with either ${ }^{35}$ S-labeled, antisense coding-region (prNT4) probe $(A)$ or ${ }^{35} \mathrm{~S}$-labeled, antisense intron-specific (pNTgHX) probe $(B)$. Dark grains over stained neurons indicate hybridization-positive cells (arrows). Figure $8 C$ is a low-magnification, dark-field photomicrograph through the same region of the striatum following in situ hybridization with labeled sense probe transcribed from pNTgHX. Autoradiograms were generated by coating the brain sections with Kodak NTB2 emulsion and developing after a $6 \mathrm{~d}$ (coding region probe) or $15 \mathrm{~d}$ (intron-derived probes) exposure.

accumulation of mature NT/N mRNA in the dorsolateral striatum. The specificity of the intron-specific probe for NT primary transcripts was also evident from the distinct nuclear localization of hybridization signal and the failure of a sense RNA probe to show any hybridization (Fig. 9). The rapid decline in levels of intron 2-containing transcripts at $3 \mathrm{hr}$ suggests that the intron sequences are rapidly degraded after splicing. It was interesting that the dorsolateral striatal neurons showed minimal expression of NT/N mRNA in the basal state (Fig. 2). It appears, therefore, that NT/N gene expression in certain populations of central neurons may depend entirely on appropriate environmental stimuli.

The transcriptional effects of haloperidol could be mediated through the cAMP pathway and the induction of immediate early genes such as c-fos as proposed in Figure 12. Blockage of $\mathrm{D}_{2}$ receptors has been shown to increase intracellular levels of cAMP and also cause transient activation of c-fos expression (Miller, 1990). Transient transfection analysis in PC12 cells, which neuronally differentiate in response to NGF, has revealed that AP-1 and cAMP-response element (CRE) sequences are required for the integration of transcriptional responses of the NT/N gene to multiple environmental stimuli (Kislauskis and Dobner, 1990). A family of genes, typified by the c-fos and c-jun proto-oncogenes, encode transcriptional factors that bind the AP-1 site with high affinity in vitro (Bartel et al., 1989). A distinct but related family of proteins bind the CRE with high affinity (Habener, 1990). A CRE-binding protein identified in PC12 cells, CREB, binds constitutively to the CRE sequences, but its ability to activate transcription is strikingly increased following phosphorylation by cAMP-dependent protein kinase (Gonzalez and Montminy, 1989). Haloperidol treatment could result in the activation of NT/N gene transcription through increased phosphorylation of a CRE-binding protein and the transient activation of AP-1-binding factors such as c-fos. The specific implication of $\mathrm{D}_{2}$ receptors in directly mediating the transcriptional effects of haloperidol on NT/N gene expression requires further study. However, removal of tonic $\mathrm{D}_{2}$ receptor activity has been implicated in the haloperidol-induced increase in striatal NT content (Merchant et al., 1989). A potential role of cAMP in regulation of NT/N gene transcription is also supported by the observation that activation of $\mathrm{D}_{1}$ receptors (positively linked to adenylate cyclase) increases NT content while $\mathrm{D}_{2}$ receptor activation (negatively linked to adenylate cyclase) decreases NT content in the striatum (Merchant et al., 1988b). Thus, it appears likely that haloperidol influences NT/N gene transcription, in part, by altering intracellular cAMP levels, possibly via blockade of $\mathrm{D}_{2}$ receptors.

Based on the data presented here, an increase in NT biosynthesis in the caudate-putamen appears to occur following treatment with haloperidol. However, Bean et al. (1989) have reported that reserpine-induced increases in NT content in the neostriatum may be due to blockade of NT release rather than an increase in its biosynthesis. Since the effect of reserpine on NT content appears to be due to removal of $\mathrm{D}_{2}$ receptor tone (Merchant et al., 1989), the data presented here appear to be inconsistent with the observations of Bean et al. (1989). However, it is likely that NT terminals originating outside the striatum may be regulated differently by reserpine as compared to the cell bodies present within the striatum. Reserpine may, for example, decrease the release from terminals of extrinsic neurons and yet increase the synthesis of the peptide in discrete intrinsic neurons in the striatum, the net effect of which will be an increase in the peptide content. On the other hand, subpopulations of NT neurons originating in the striatum may be regulated distinctly by dopaminergic blockers. The technique of in situ hybridization histochemistry used in the present study offers 

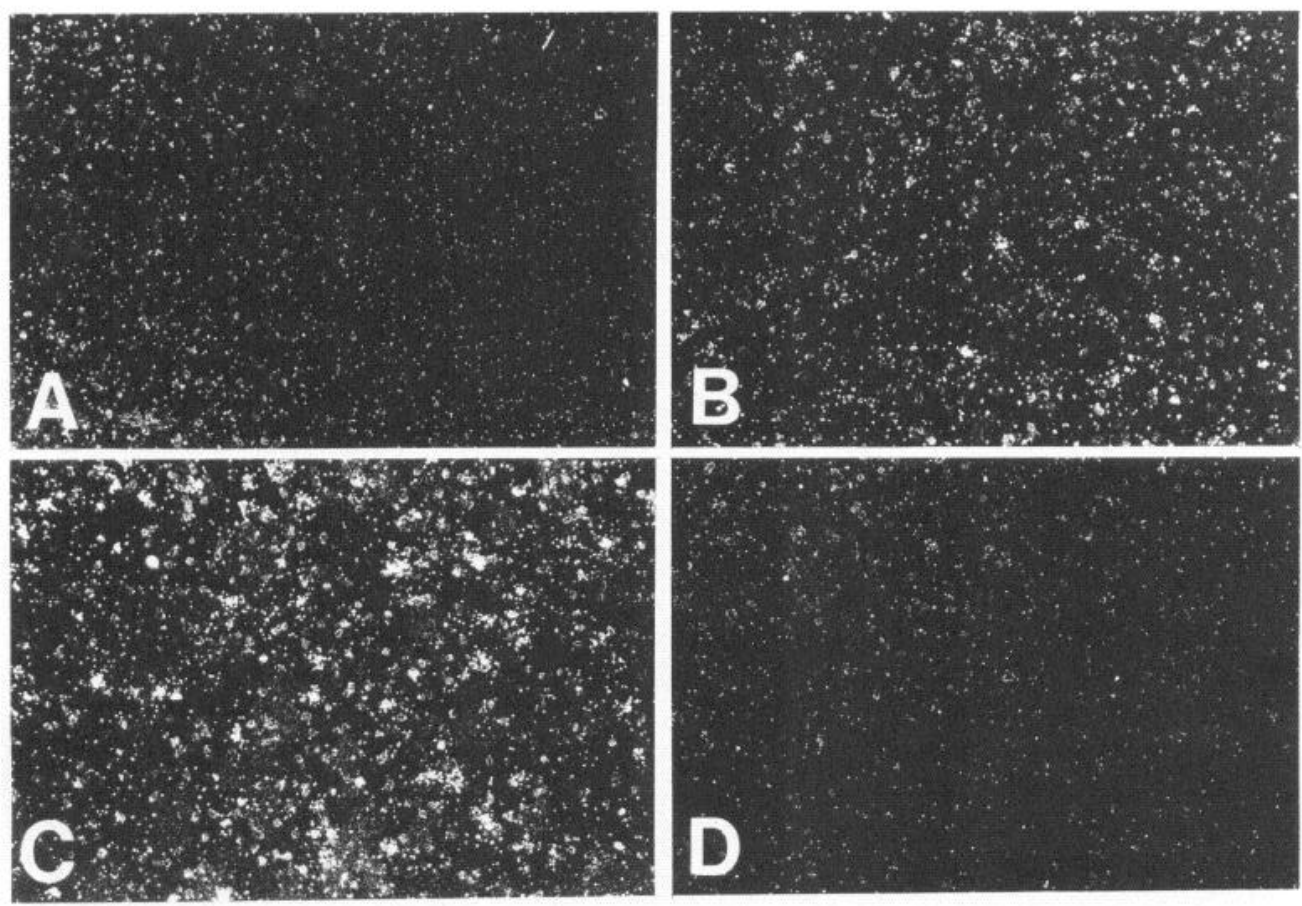

Figure 10. Dark-field photomicrographs showing the time course of haloperidol induction of intron-containing NT/N transcripts. Brain sections adjacent to those used in the study described in Figure 1 were hybridized with ${ }^{35} \mathrm{~S}$-labeled, antisense intron-specific probe (pNTgHX). Autoradiograms were generated by $15 \mathrm{~d}$ exposure to Kodak NTB2 emulsion. Clusters of silver grains in the high-magnification, dark-field photomicrographs indicate NT/N primary transcript-containing cells in the dorsolateral striatum from a control brain $(A)$ or from haloperidol-treated rats at $0.5 \mathrm{hr}(B), 1 \mathrm{hr}(C)$, or $3 \mathrm{hr}(D)$ following treatment. the advantage of excellent anatomical resolution to identify discrete NT systems that may be differentially regulated.

In summary, our results indicate that both haloperidol and clozapine increase the expression of NT/N mRNA and hence possibly the biosynthesis of this peptide in the neostriatum. However, there are significant anatomical differences in the neurons targeted by these two drugs, suggesting that a functional diversity may exist among subpopulations of striatal NT neurons. Future studies with a variety of antipsychotic drugs can be used to determine whether specific NT neuronal populations in the striatum represent distinct substrates of typical and atypical antipsychotics, thereby resulting in the unique pharmacological and behavioral profiles of these two classes of drugs.
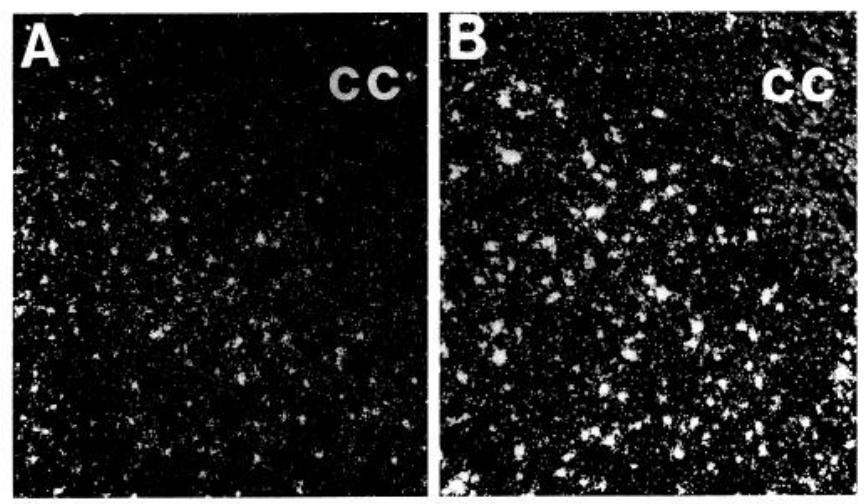

Figure 11. Comparison of anatomical localization of hybridization signal generated by coding region and intron-derived probes. Low-magnification, dark-field photomicrographs represent autoradiograms through the dorsolateral striatum generated in the studies described in Figures 1 and 9. $A$ and $B$ represent typical autoradiograms from haloperidol-treated animals at 1 and $7 \mathrm{hr}$, respectively, following hybridization with the intron-specific probe $(A)$ or coding region probe $(B)$. $c c$, Corpus collosum.

\section{References}

Alexander MJ, Miller MA, Dorsa DM, Bullock BP, Melloni RH Jr, Dobner PR, Leeman SE (1989) Distribution of neurotensin/neuromedin $\mathrm{N}$ mRNA in rat forebrain: unexpected abundance in hippocampus and subiculum. Proc Natl Acad Sci USA 86:5202-5206.

Angulo JA, Cadet JL, Woolley CS, Suber F, McEwen BS (1990) Effects of chronic typical and atypical neuroleptic treatment on proenkephalin mRNA levels in the striatum and nucleus accumbens of the rat. J Neurochem 54:1889-1894.

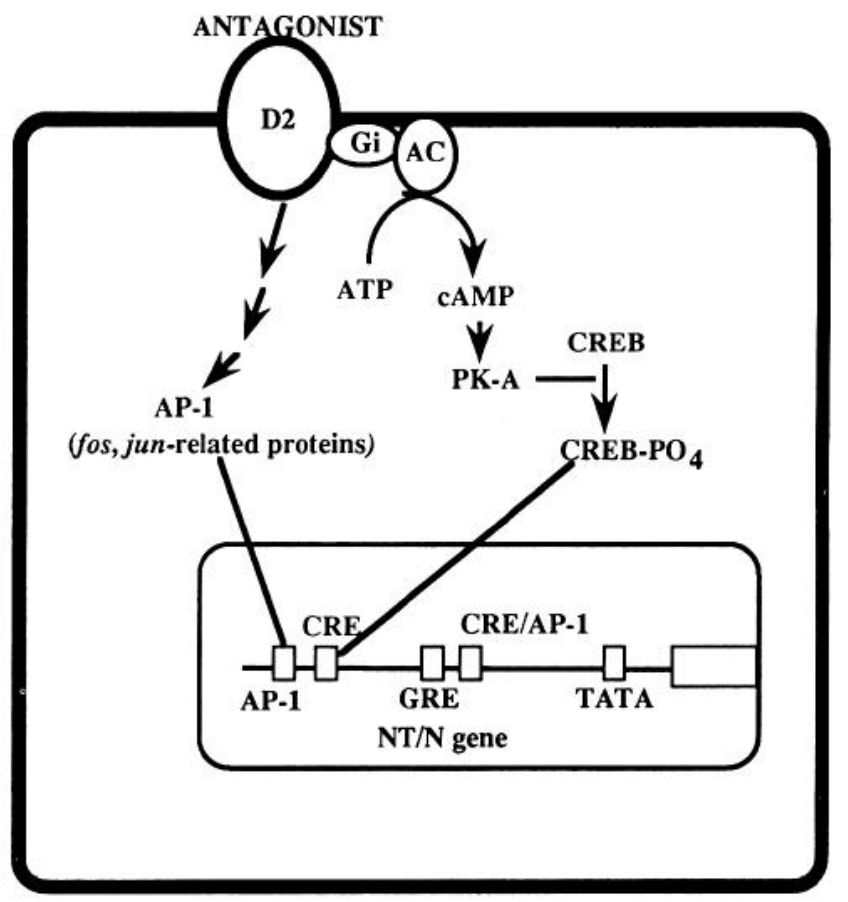

Figure 12. Proposed theoretical model for dopamine $\mathrm{D}_{2}$ receptor mediated regulation of NT/N gene transcription. See text for discussion. $\mathrm{Gi}$, inhibitory $\mathrm{G}$ protein; $\mathrm{AC}$, adenylate cyclase. 
Bartel DP, Sheng M, Lau LF, Greenberg ME (1989) Growth factors and membrane depolarization activated distinct programs of early response gene expression: dissociation of fos and jun induction. Genes Dev 3:304-313.

Bean AJ, During MJ, Deutch AY, Roth RH (1989) Effects of dopamine depletion on striatal neurotensin: biochemical and immunocytochemical studies. J Neurosci 9:4430-4438.

Bissette G, Nemeroff CB, Prange AJ Jr, Loosen PT, Lipton MA (1976) Hypothermia and intolerance to cold induced by intracisternal administration of the hypothalamic peptide, neurotensin. Nature 262: 607-609.

Carlsson A (1967) Basic action of psychoactive drugs. Int J Neurol 6: 27-31.

Carraway R, Leeman SE (1973) The isolation of a new hypotensive peptide, neurotensin, from bovine hypothalami. J Biol Chem 248: 6854-6861.

Chiodo LL, Bunney BS (1983) Typical and atypical neuroleptics: differential effects of chronic administration on the activity of A9 and A10 dopaminergic neurons. J Neurochem 3:1617-1619.

Chomczynski P, Sacchi N (1987) Single step method of RNA isolation by acid guanidinium thiocyanate-phenol-chloroform extraction. Anal Biochem 162:156-159.

Creese I, Burt DR, Snyder SH (1976) Dopamine receptor binding predicts clinical and pharmacological potencies of antipsychotic drugs. Science 192:481-483.

Deutch AY, Cameron DS (1991) Pharmacological characterization of dopamine systems in the nucleus accumbens core and shell. Neuroscience, in press.

Eggcrman KW, Zahm DS (1988) Numbers of neurotensin-immunoreactive neurons selectively increased in rat ventral striatum following acute haloperidol administration. Neuropeptides 11:125-132.

Emson PC, Goedert M, Mantyh PW (1985) Neurotensin-containing neurons. In: Handbook of neuroanatomy: GABA and neuropeptides in the CNS, Pt I (Bjorklund A, Hokfelt T, eds), pp 355-405. Amsterdam: Elsevier.

Ervin GN, Birkemo LS, Nemeroff CB, Prange AJ Jr (1981) Neurotensin blocks certain amphetamine-induced behaviours. Nature 291: 73-76.

Fann WE, Lake CR (1976) Amantidine versus trihexyphenidyl in the treatment of neuroleptic-induced parkinsonism. Am J Psychiatry 133: 940-943.

Fremeau RT Jr, Autelitano DJ, Blum M, Wilcox J, Roberts JL (1989) Intervening sequence-specific in situ hybridization: detection of proopiomelanocortin gene primary transcript in individual neurons. Mol Brain Res 6:197-201.

Frey $P$ (1983) Cholecystokinin octapeptide levels in rat brain are changed after subchronic neuroleptic treatment. Eur J Pharmacol 95: 87-92.

Frey P, Fuxe K, Eneroth P, Agnati LF (1986) Effects of acute and long-term treatments with neuroleptics on regional telencephalic neurotensin levels in the male rat. Neurochem Int 8:429-434.

Gerfen CR, Engber TM, Mahan LC, Susel Z, Chase TN, Monsma FJ Jr, Sibley DR (1990) $D_{1}$ and $D_{2}$ dopamine receptor-regulated expression of striatonigral and striatopallidal neurons. Science 250:14291432.

Gerlach J, Koppelhus P, Helweg E, Monrad A (1975) Clozapine and haloperidol in a single-blind cross-over trial: therapeutic and biochemical aspects in the treatment of schizophrenia. Acta Psychiatr Scand 50:410-414.

Gonzalez GA, Montminy MR (1989) Cyclic AMP stimulates somatostatin gene transcription by phosphorylation of CREB at serine 133. Cell 59:675-680.

Govoni S, Hong JS, Yang HY-T, Costa E (1980) Increase of neurotensin content elicited by neuroleptics in nucleus accumbens. J Pharmacol Exp Ther 215:413-417.

Guyette WA, Matusik RJ, Rosen JM (1979) Prolactin-mediated transcriptional and post-transcriptional control of casein gene expression. Cell 17:1013-1023.

Habener JF (1990) Cyclic AMP response element binding proteins: a cornucopia of transcriptional factors. Mol Endocrinol 4:1087-1094.

Heimer L, Zahm DS, Churchill L, Kalivas PW, Wohltmann C (1991) Specificity in the projection patterns of accumbal core and shell. Neuroscience 41:89-126.

Hynes NE, Groner B, Sippel AE, Jeep S, Wurtz T, Nguyen-Huu MC, Giesecke K, Schutz G (1979) Control of cellular content of chicken cgg white protein specific RNA during estrogen administration and withdrawal. Biochemistry 18:616-624.

Iversen LL, Iversen SD, Bloom FE, Douglas C, Brown M, Vale W (1978) Calcium-dependent release of somatostatin and neurotensin in rat brain, in vitro. Nature 273:161-163.

Kalivas PW, Burgess SK, Nemeroff CB, Prange AJ Jr (1983) Behavioral and neurochemical effects of neurotensin microinjection into the ventral tegmental area. Neuroscience 8:495-505.

Kilts CD, Anderson CM, Bissette G, Ely TD, Nemeroff CB (1988) Differential effects of antipsychotic drugs on the neurotensin concentration of discrete rat brain nuclei. Biochem Pharmacol 37:15471554.

Kislauskis E, Dobner PR (1990) Mutually dependent response elements in the cis-regulatory region of the neurotensin/neuromedin $\mathrm{N}$ gene integrate environmental stimuli in PC12 cells. Neuron 4:783795 .

Kitabgi P, Carraway R, Van Rietschoten J, Granier B, Morgat JL, Menez A, Leeman SE, Freychet P (1977) Neurotensin: specific binding to synaptic membranes from rat brain. Proc Natl Acad Sci USA 74: $1846-1850$.

Letter AA, Merchant KM, Gibb JW, Hanson GR (1987) Effect of methamphetamine on neurotensin concentrations in rat brain regions. J Pharmacol Exp Ther 241:443-447.

Levant B, Merchant KM, Dorsa DM, Nemeroff CB (1991) BMY 14802 , a potential antipsychotic drug increases expression of proneurotensin mRNA in the rat striatum. Mol Brain Res, in press.

McEvoy JP (1983) The clinical use of anticholinergic drugs as treatment for extrapyramidal side effects of neuroleptic drugs. J Clin Psychopharmacol 3:288-302.

McKnight GS, Palmiter RD (1979) Transcriptional regulation of the ovalbumin and conalbumin genes by steroid hormones in chick oviduct. J Biol Chem 254:9050-9058.

Meador-WoodruffJH, Mansour A, Bunzow JR, Van Tol HHM, Watson SJ Jr, Civelli O (1989) Distribution of $\mathrm{D}_{2}$ dopamine receptor $\mathrm{mRNA}$ in rat brain. Proc Natl Acad Sci USA 86:7625-7628.

Melton DA, Krieg PA, Rebagliati MP, Maniatis T, Green MR (1984) Efficient in vitro synthesis of biologically active RNA and RNA hybridization probes from plasmids containing a bacteriophage SP6 promoter. Nucleic Acids Res 12:7035-7056.

Merchant KM, Letter AA, Gibb JW, Hanson GR (1988a) Changes in the limbic neurotensin systems induced by dopaminergic drugs. Eur J Pharmacol 153:151-154.

Merchant KM, Gibb JW, Hanson GR (1988b) Role of dopamine D-1 and D-2 receptors in regulation of neurotensin systems in the neostriatum and the nucleus accumbens. Eur J Pharmacol 160:409_ 412.

Merchant KM, Bush LG, Gibb JW, Hanson GR (1989) Dopamine D-2 receptors exert tonic regulation of discrete neurotensin systems of the rat brain. Brain Res 500:21-29.

Merchant KM, Miller MA, Ashleigh EA, Dorsa DM (1991) Haloperidol rapidly increases the number of neurotensin mRNA-expressing neurons in the neostriatum of the rat brain. Brain Res 540:311-314.

Miller JC (1990) Induction of c-fos mRNA expression in rat striatum by neuroleptic drugs. J Neurochem 54:1453-1455.

Nemeroff CB (1980) Neurotensin: perchance an endogenous neuroleptic? Biol Psychiatry 15:283-302.

Nemeroff CB, Luttinger D, Fernandez DE, Mailman RB, Mason GA, Davis SD, Widerlöv E, Frye GD, Kilts CD, Beaumont K, Breese GR, Prange AJ Jr (1983) Interactions of neurotensin with dopamine systems: biochemical and behavioral studies. J Pharmacol Exp Ther 225:337-345.

Palkovits M, Brownstein MJ (1988) Maps and guide to microdissection of the rat brain. New York: Elsevier.

Paul M, Wagner D, Metzger R, Ganten D, Lang RE, Suzuki F, Murakami K, Burbach JH, Ludwig G (1988) Quantification of renin mRNA in various mouse tissues by a novel solution hybridization assay. $J$ Hypertens 6:247-252.

Paxinos G, Watson C (1986) The rat brain in stereotaxic coordinates. Sydney, Australia: Academic.

Quirion R (1983) Interactions between neurotensin and dopamine in the brain: an overview. Peptides 4:609-615.

Sambrook J, Fritsch EF, Maniatis T (1989) Molecular cloning: a laboratory manual (Ford N, ed). Cold Spring Harbor, NY: Cold Spring Harbor Laboratory. 
Seeman P (1987) Dopamine receptors and the dopamine hypothesis of schizophrenia. Synapse 1:133-152.

Seeman P, Lee T, Chau-Wing M, Wong K (1976) Antipsychotic drug doses and neuroleptic/dopamine receptors. Nature 261:717-718.

Uhl GR (1982) Distribution of neurotensin and its receptors in central nervous system. Ann NY Acad Sci 400:132-149.

Uhl GR, Snyder SH (1976) Regional and subcellular distributions of brain neurotensin. Life Sci 19:1827-1832.

Van Tol HHM, Bunzow JR, Guan H-C, Sunahara RK, Seeman P, Niznik HB, Civelli $O$ (1991) Cloning of the gene for human $D_{4}$ receptor with high affinity for the antipsychotic clozapine. Nature 350:610-614

White FJ, Wang RY (1983) Differential effects of classical and atypical antipsychotic drugs on $\mathrm{A} 9$ and $\mathrm{A} 10$ dopamine neurons. Science 221: $1054-1056$.

Widerlöv E, Kilts CD, Mailman RB, NemeroffCB, McCown TJ, Prange
AJ Jr, Breese GR (1982a) Increase in dopamine metakolites in rat brain by neurotensin. J Pharmacol Exp Ther 222:1-6.

Widerlöv E, Lindström LH, Besev G, Manberg PJ, NemeroffCB, Breese GR, Kizer JS, Prange AJ Jr (1982b) Subnormal CSF levels of neurotensin in a subgroup of schizophrenic patients: normalization after neuroleptic treatment. Am J Psychiatry 139:1122-1126.

Williams FG, Murtaugh MP, Beitz AJ (1990) The effect of acute haloperidol treatment on brain proneurotensin mRNA: in situ hybridization analyses using a novel fluorescence detection procedure. Mol Brain Res 7:347-358.

Young WS III, Kuhar MJ (1981) Neurotensin receptor localization by light microscopic autoradiography in rat brain. Brain Res 206: 273-285.

Zahm DS (1989) The ventral striatopallidal parts of the basal ganglia in the rat: compartmentation of ventral pallidal efferents. Neuroscience 30:33-50. 